\title{
设计末来的理想街道 \\ LET US DESIGN STREETS FOR THE FUTURE WE WANT
}

安基塔 - 查克拉 美国国家城市交通运输官方协会全球城市设计倡议旗下项目负责人

梅琳达 · 汉森 美国国家城市交通运输官方协会全球城市设计倡议副总负责人

Ankita CHACHRA* Program Manager, Global Designing Cities Initiative,

National Association of City Transportation Officials

Melinda HANSON Deputy Director, Global Designing Cities Initiative, National

Association of City Transportation Officials

* I20 Park Ave, 20th
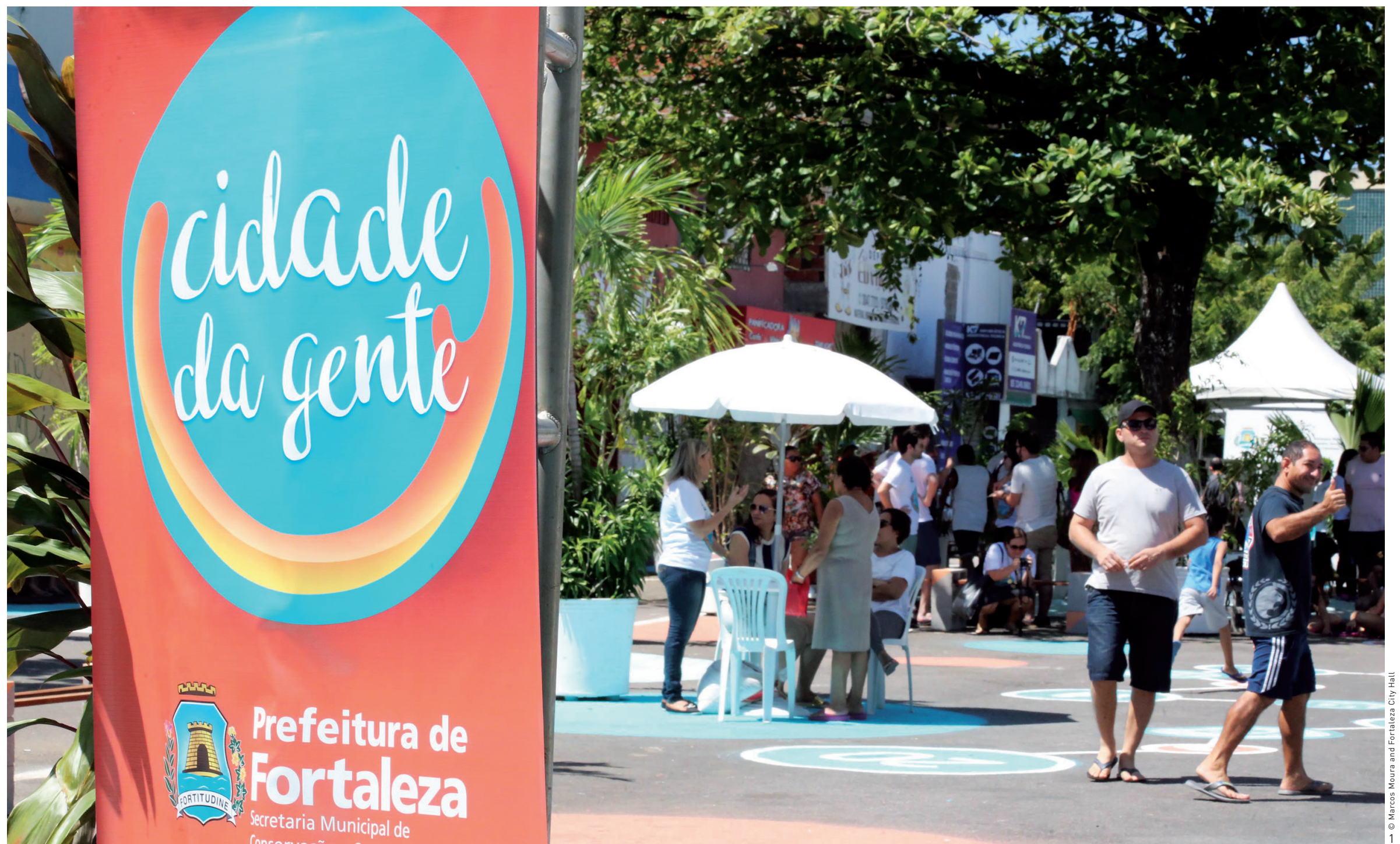

市推出了人居城市项目

1. Fortaleza launched Cidade da Gente Program in September 2017
街道不仅仅是人们活动的通道一它们 组成了城市中最大的公共空间网络, 平均占 城市总面积的 $30 \%$ 以上。除了能够满足人们 的通勤需求, 街道还提供了与朋友相会, 以 及供孩子们玩要的重要空间。它们是商店的 前厅, 也是住家的后院。

然而, 当前大多数街道设计并没有发 挥出街道的最大潜力。街道空间的分配通常 有失公平, 大部分空间都被交予私家汽车驾 驶者。许多街道缺乏人行道、自行车道、换 乘空间和其他用于确保安全和可持续交通的 元素。因此, 许多城市的街道拥堵不堪、环 境脏乱。交通事故是导致死亡的主要诱因之 一, 超过半数的受害者都是行人或自行车、 摩托车骑行者一一而步行或骑行恰恰是城市 低收入居民的主要出行方式。

当前城市街道所存在的诸多问题, 归 根结底来源于设计而非技术层面。许多人认 为, 大数据时代的到来, 或是依赖人工智能 网络的无人驾驶汽车的问世, 是解决街道问 题的有效方法。的确, 这些技术必然会重塑 我们的交通运输系统并提供针对某些问题的 解决方案, 但其并非万能, 亦会带来新的困 境与挑战。与其将高科技视为唯一的治病良 药, 不如立即采取行动重新考量街道的空间 分配及设计理念, 将人的需求放在首位。事
实上，低技术的设计方案同样能够提高人们 的出行效率并有效改善城市环境。

世界各个城市的实践经验表明, 将街道 设计为 “服务于人的场所” 有助于确保未来 的交通系统更加安全、公平和高效。以巴西 的福塔雷萨市为例, 该市致力于提高可持续 交通模式的可实施性和道路安全。尽管资源 有限, 但在过去的 4 年里, 该市大幅扩建了 自行车道网络, 增设了自行车共享系统, 并采用新型街道设计方法提升道路安全。 如 “人居城市”方案这类由社区主导的项 目, 也在试图将停车场改造为充满活力的 公共空间。通过这些举措, 自2010年至 今, 福塔雷萨市的交通事故发生量减少了 约35\%, 并成为拉丁美洲使用共享单车人 数最多的城市。最重要的是, 社区主导的 公共空间和道路安全项目得到了9 $4 \%$ 的民 众的认可。

新西兰的奥克兰市也在街道可达性和宜 居性上取得了突破性进展。在转变街道设计 目标后, 行人、自行车骑行者和交通换乘者 的需求优先得到了满足。该市还选择在市中 心的街道上架设轻轨交通系统, 这一决策也 表明他们在进行投资时主动将居民通行需求 放在了首位。受益于针对公共交通进行的一 系列战略投资，该市公共交通乘客量在十年
https://doi.org/10.15302/J-LAF-20180213 收瑅时间 RECEIVED DATE / 2018-04-20 中图分类号 / TU984 文献标识码/

本文旨在呼吁人们关注街道设计在引入和优先考虑某些 用途时的作用, 并突显了世界各个城市为将街道从汽车导向 转变为居民导向所付出的努力。身处当今时代, 我们对于未 来街道的畅想被无人驾驶汽车的问世所蒙蔽和限制，却忽视 了利用低技术的解决方案有效改善城市环境的可能。本文吁 叮人们等快平取行动以改变当下或行的街道设计方法, 并将

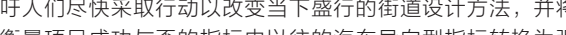
衡量项目成功与否的指标由以往的汽车导向型指标转换为强 调可达性、安全性、空间公平分配、环境质量、公共健康和 整体生活质量的指标。从业者和决策者不应想当然地认为当 今城市面临的所有挑战都可以通过技术来解决, 而应着重发 展那些采纳了优选高效通勤方式且有助于创建市民友好型城 市的街道设计。

关键词

街道设计; 公平城市; 社区参与; 公共生活; 道路安全

\section{ABSTRACT}

This article will call attention to the role of street design in inviting and prioritizing certain uses and highlight efforts made by cities across the globe to move away from caroriented and toward people-oriented streets. There are many low-technology solutions available to create better cities, and yet, we are in an era where the vision for the future of streets is clouded by the advent of autonomous vehicles. This article will will enp a tize the prevailing approach to street design and shift the measure of success away from car-oriented metrics and toward metrics that address access, safety, equitable distribution of space, environmental quality, public health, and overall quality of life. Practitioners and decision-makers should not assume that technology will solve the challenges cities are facing today and should focus first on designing streets that prioritize the most efficient modes of transport and create people-friendly cities. KEY WORDS

KEY WORDS
Street Design; Equitable Cities; Community Engagement; Public Life; Road Safety

译 黄延峰 陆小㻢

TRANSLATED BY Yanfeng HUANG Xiaoxuan LU 
内翻了一番。此外, 该市还将一座老旧高架 道路改造为一条贯通多个关键性节点的亮粉 色自行车高速路。这条被称作 “光之路” 的 新走廊在开通第一个月内就创下了总骑行次 数超过三万次的记录。

福塔雷萨市、奥克兰市和全球许多其他 城市都在重构和改变其街道, 以采取更公平 的方式满足市民的通行需求。尤其值得一提 的是, 这些城市的决策者重新确定了影响街 道空间分配的常用指标, 从优先注重汽车行 车体验, 转变为以可达性、环境质量、公共 健康和整体生活质量等方面的指标来衡量街 道设计的优劣。现在, 福塔雷萨市不再以汽 车服务等级为街道考评指标, 而代之以新建 自行车道公里数。同时, 扩建的道路还使得 低收入社区居民的交通出行变得更加便捷。 而在奥克兰市, 街道考评指标也由机动车总 容量转变为通行人数总容量。通过优先考虑 那些以人的体验为核心的指标, 空间的分配 结果将更加公平, 运输系统将更加高效, 街 道也将更加宜人。

上述案例非常值得其他城市借鉴。自动 化和大数据不一定是解决当前街道普遍存在 的安全、拥堵、不平等等问题的最优方法。 从福塔雷萨市和奥克兰市的案例——以及 收录于《全球街道设计指南》中的更多案例 中一一我们不难看出, 低技术的解决方案在
提升人群流动性和道路安全及改善城市环境 等方面亦颇有成效。该指南是隶属于“全球 城市设计倡议”的项目之一, 该倡议关注街 道在全球城市环境中扮演的关键性角色。而 上述指南则收集了来自全球 42 个国家的 72 座城市的专家意见及案例分析, 提供了以步 行者、骑行者以及公交搭乘者为优先的街道 设计技术细节。

无论人工智能技术将把汽车产业引向 何处, 优质街道的设计基准不会改变。因为 不论何时, 街道都应满足行人不时穿越街道 的需求, 都需在十字路口设置收窄的转弯半 径来约束车辆进行减速, 也应赋予交通换乘 者足够的换乘空间。我们可以、也应该从现 在开始设计满足上述要求的街道。尽管新技 术的出现能够让从业者有机会在不久的将来 重新设计我们的街道, 并纠正一个世纪以来 以汽车为导向的城市规划所犯下的错误, 但 我们没有理由在 “新技术的奇迹”上孤注一 掷。事实上, 我们可以从下一秒开始, 重拾 城市街道生活最本质的逻辑! 让我们借此契 机重塑街道, 使其对于所有使用者来说都更 加安全。与其重复过去的错误, 并盲目依赖 汽车技术的进步, 不如改变我们衡量街道性 能的标准。不管是过去、现在, 还是未来, 城市街道设计都应该关注人的体验, 因为人 才是城市存在的基础。LAF
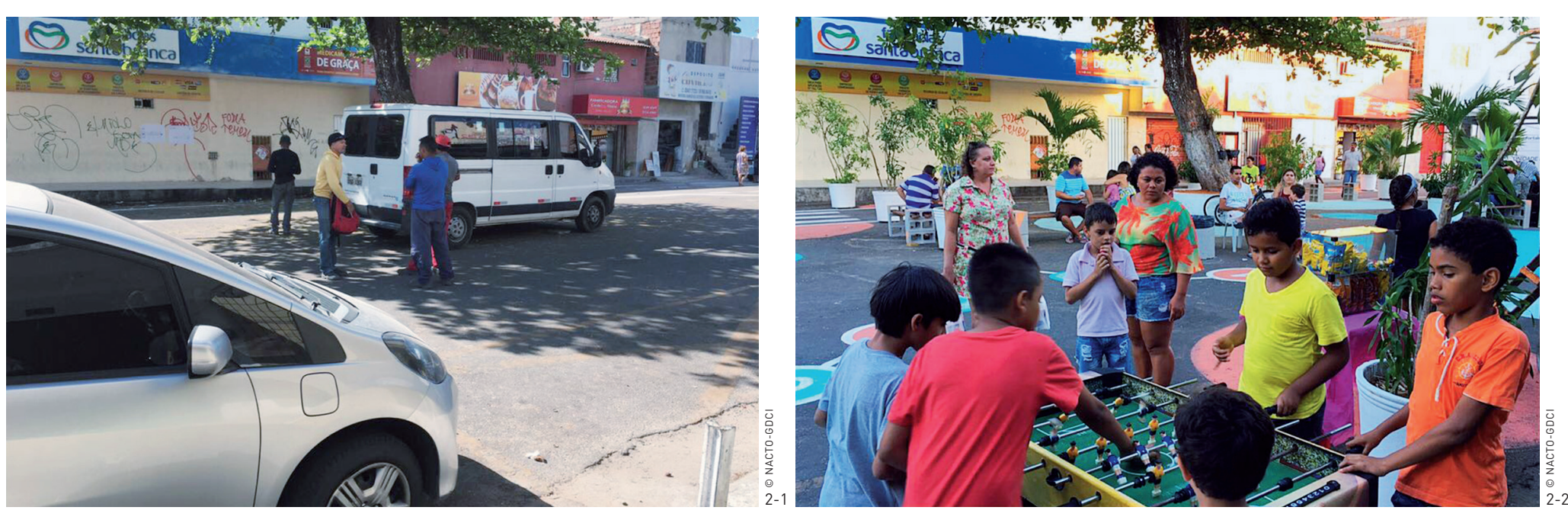


\begin{tabular}{|c|c|c|}
\hline $\begin{array}{l}\text { 停车场改造前后对比 } \\
\text { 图: 未得到充分利用的 } \\
\text { 停车场被转变为了适合 } \\
\text { 各年龄段人群活动的充 } \\
\text { 满活力的公共空间。 } \\
\text { 一条老旧高架道路被改 } \\
\text { 造为一条贯通多个关 } \\
\text { 键性节点的亮粉色自行 } \\
\text { 车高速路, 并被命名为 } \\
\text { “光之路”。 }\end{array}$ & 3. & $\begin{array}{l}\text { Before and after images } \\
\text { showing underutilized } \\
\text { parking lot converted } \\
\text { into lively public space } \\
\text { with activities for all } \\
\text { age groups. } \\
\text { An old overpass was } \\
\text { transformed into a } \\
\text { bright pink bicycle } \\
\text { superhighway } \\
\text { that connects key } \\
\text { destinations in the city, } \\
\text { commonly referred to } \\
\text { as The Light-Path. }\end{array}$ \\
\hline
\end{tabular}

Streets are more than a conduit for movement. They are the largest network of public space in cities, on average comprising more than 30 percent of a city's total area. In addition to meeting mobility needs, they serve as places for people to meet friends and for children to play. They are the front doors to business and the backyards to homes.

And yet, most streets today are not designed to maximize their potential. Street space is unfairly allocated, with the majority given over to private motorists. Many streets lack sidewalks, cycle tracks, space for transit, and other features that would support safe and sustainable transport. Consequently, streets in many cities are congested and polluted. Road vehicle crashes are one of the leading causes of death, and more than half of traffic fatality victims are pedestrians, cyclists, or motorcyclists - the primary modes for lowincome urban residents.

The current state of urban streets is, in many ways, a design problem. While we prepare for the era of big data and autonomous vehicles - which is certain to reshape our transport system, bringing new solutions and challenges - we need

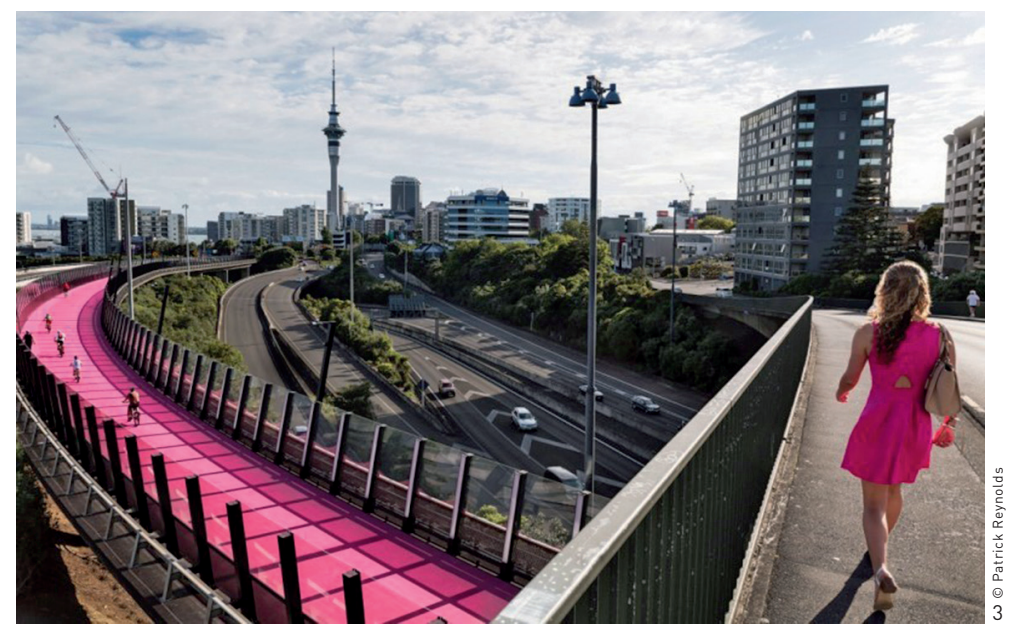

to act now to redistribute street space and redesign streets to prioritize people. In fact, there are low-technology design solutions available to improve mobility and create better cities.

Cities around the world are proving that if streets are designed as places for people, they can help ensure a transport future that is safer, more equitable, and more efficient. Fortaleza, Brazil, for example, has committed to improving access to sustainable transport modes and improving road safety. Despite limited resources, in the last four years, the city has dramatically expanded its bikeway network, added bike share systems, and introduced new street design approaches to improve road safety. Community-driven programs like "Cidade de Gente" (The City for People) are reclaiming parking lots to provide lively public spaces. Through interventions like these, Fortaleza has reduced traffic fatalities by approximately 35 percent since 2010, achieved the highest bikeshare ridership in Latin-America and, most importantly, won a 94 percent approval rate for community-driven public space and road safety programs.

Similarly, Auckland, New Zealand has made great strides toward becoming more accessible and livable by repurposing streets to give priority to pedestrians, cyclists, and transit riders. The city opted to give street space to a light rail system in its city center, a decision that actively puts the movement of people at the forefront of their investment. With strategic investments in public transport, the city has doubled transit ridership within 10 years. Further, the city repurposed an old overpass and transformed it into a bright pink bicycle superhighway that connects key destinations. Commonly referred to as The Light-Path, the new corridor recorded over 30,000 trips in its first month of operation.

Fortaleza, Auckland, and many other cities across the globe are reimagining and transforming their streets to more equitably address the mobility needs of their citizens. Crucially, decision-makers in these cities have redefined the metrics that typically inform allocation of street space, moving away from those that prioritize cars to instead measure performance on the basis of access, environmental quality, public health, and overall quality of life. Instead of measuring level of service for cars, Fortaleza is now measuring kilometers of 


\section{Two-way Protected Bikeway 双向自行车专用道

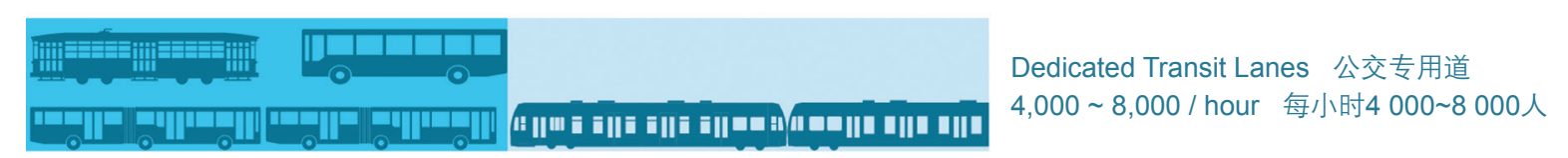

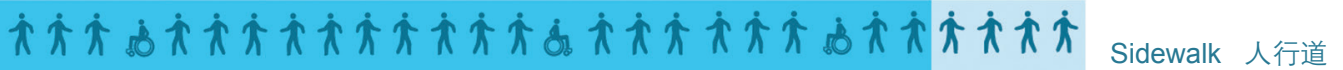

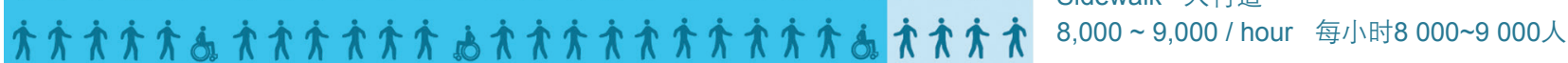

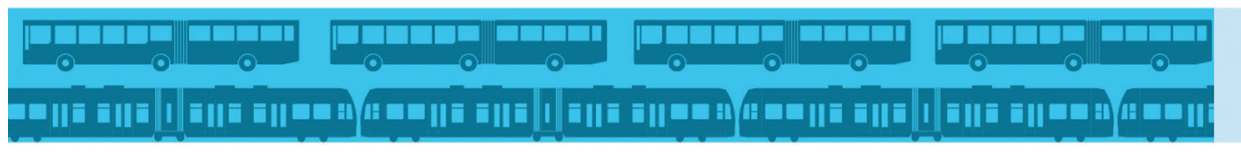

On-street Transit Way, Bus Or Rail 路面公共交通 (公交车或轨道交通) $10,000 \sim 25,000 /$ hour 每小时10 000 25 000人 new bike paths and increased transport access for low income communities, while Auckland measures the total capacity of a street (the number of people it moves) instead of the number of motor vehicles. Prioritizing metrics that measure the experience of people leads to a more equitable distribution of space, more efficient transport systems, and more livable streets.

These are the examples cities should be following. We cannot assume that automation and big data will solve issues of safety, congestion, and inequality in mobility that are currently plaguing our streets. The Fortaleza and Auckland examples - and many more that are included in the Global Street Design Guide
- demonstrate that low-technology design solutions can also effectively improve mobility, road safety, and generally create better cities. Developed under the umbrella of Global Designing Cities Initiative (GDCI), which focuses on the critical role of streets within urban environments around the world, the Global Street Design Guide offers technical details to inform street design that prioritizes pedestrians, cyclists, and transit riders, with the input of experts from 72 cities in 42 countries.

The fundamentals of good street design will remain the same regardless of how Artificial Intelligence will reshape the automotive industry. Pedestrians will still need frequent opportunities to cross

$\begin{array}{lll}\text { 4. 不同交通方式下的运输 } & \text { 4. } & \text { People capacity of } \\ \text { 总人数。图片显示了高 } & \text { different modes. The } \\ \text { 峰期时正常情况下不同交 } & \text { illustration shows } \\ \text { 通方式在3m宽的车道上每 } & \text { the hourly capacity } \\ \text { 小时运输的总人数。 } & \text { of a } 3 \text { m-wide lane by } \\ \text { 5. 在充分考虑现有街道设计 } & \text { different modes at peak } \\ \text { 和项目目标的前下, } & \text { conditions with normal } \\ \text { 《全球街道设计指南》检 } & \text { operations. } \\ \text { 验了可能实现的基础设施 } & \text { 5. } & \text { The Global Street } \\ \text { 改造方案。这些方案能够 } & \text { Design Guide } \\ \text { 促使城市提高公共空间利 } & \text { examines achievable } \\ \text { 用率、优化建成场所、激 } & \text { infrastructure changes, } \\ \text { 发经济活力, 同时也有助 } & \text { taking into account } \\ \text { 于提开街道安全和各种交 } & \text { existing street design } \\ \text { 通方式的移动效率。 } & \text { and project goals. } \\ & \text { These improvements } \\ & \text { allow cities to best } \\ & \text { utilize their public } \\ & \text { space, enhance existing } \\ & \text { places, and foster } \\ & \text { economic activity. } \\ & \text { These changes aid } \\ & \text { in promoting traffic } \\ & \text { safety and efficient } \\ & \text { movement of all modes } \\ & \text { of transport. }\end{array}$



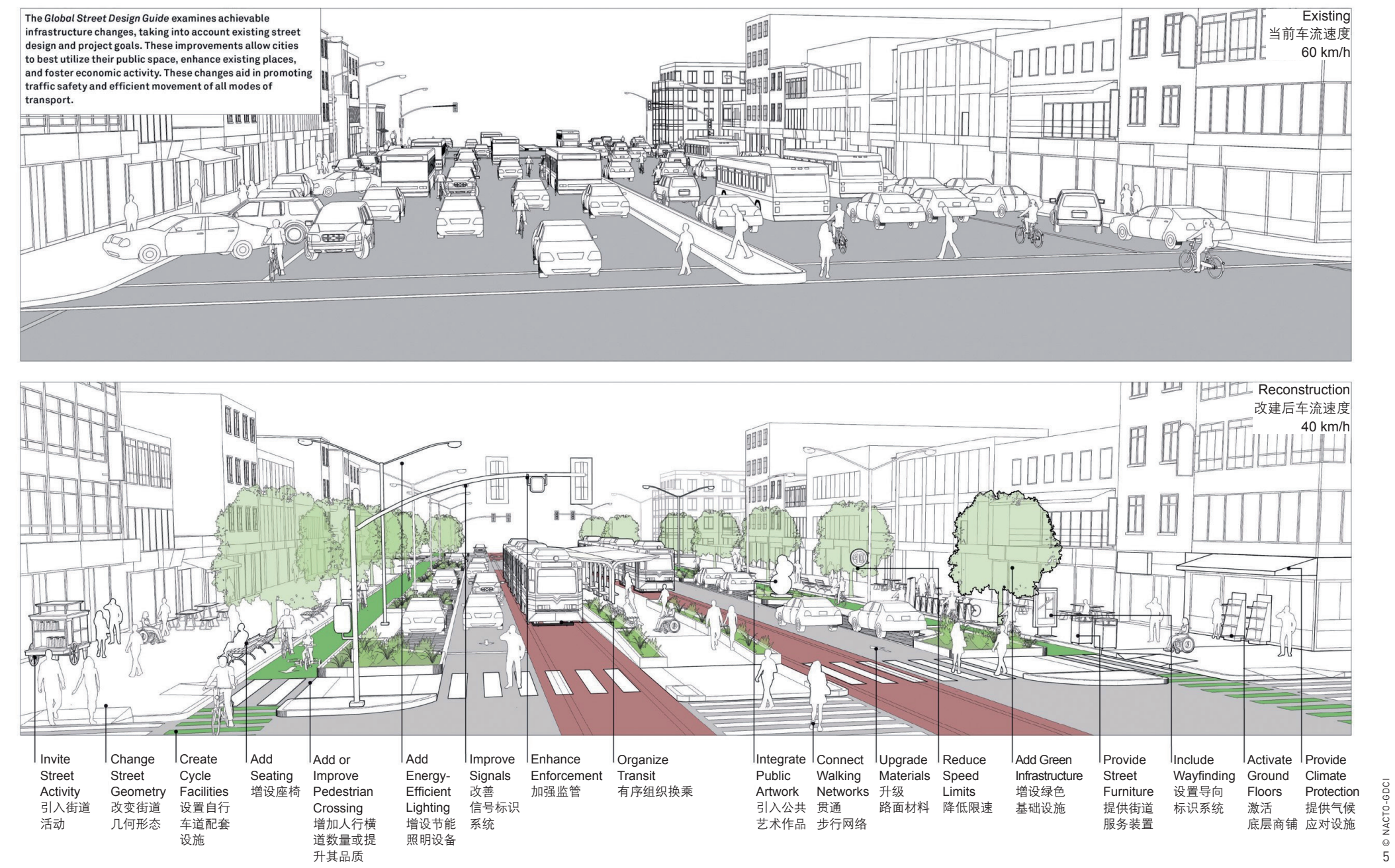

6. 在设计街道时优先考虑 人的需求, 将人置于金 字塔顶层。

6. Prioritizing people in street designs and placing them on top of the hierarchy pyramid the street at-grade, vehicles will need to be slowed at intersections through tightened curb radii, and transit riders will need safe spaces to wait and board. These are things that can - and should - be done today. While new technologies will give practitioners an opportunity to redesign our streets and to correct the mistakes of a century of urban planning, there is no reason to wait. We say let us start now. Let us use this opportunity to reclaim our streets and make them safer for all users. Instead of repeating past mistakes and relying on private car technology, let us change the way we measure the performance of our streets. The past, present, and future of our cities is people and it is time we design for them. LAF

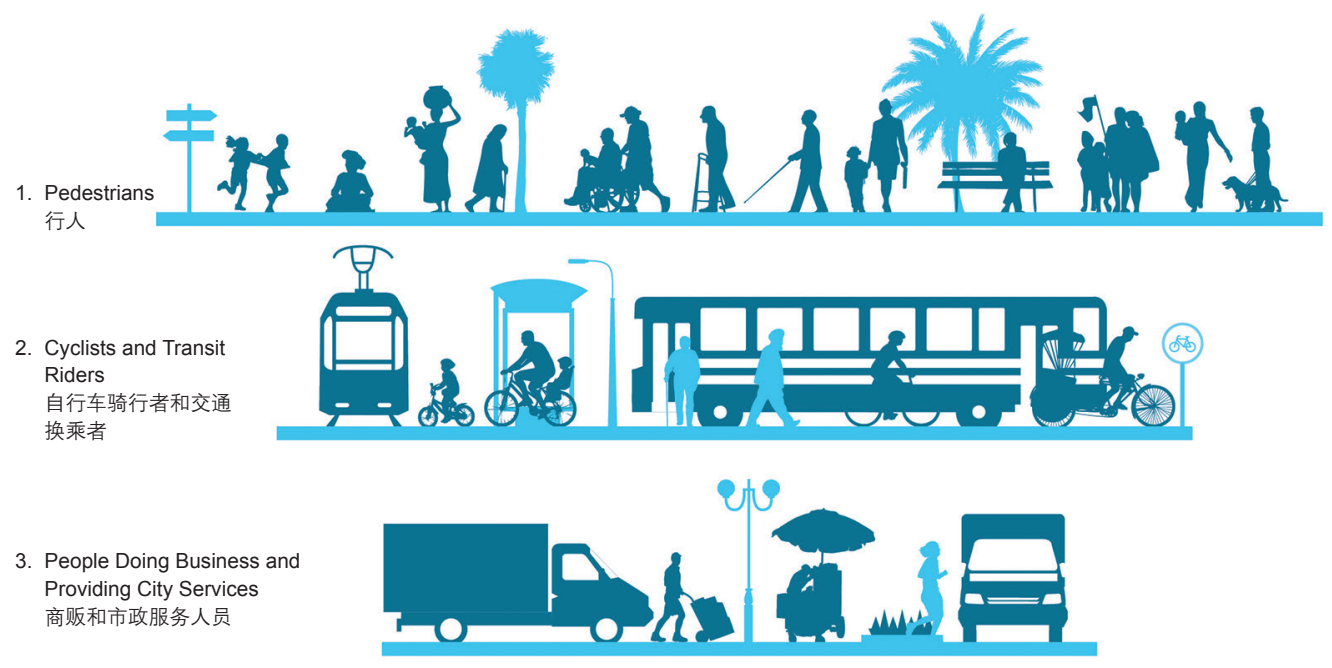

4. People in Personal Motorized Vehicles 私家车驾驶者 